Jurnal Bisnis dan Manajemen, Volume 19, No. 2, September 2018, p. 88-100

\title{
DETERMINANTS OF ORGANIZATIONAL CITIZENSHIP BEHAVIOR: THE CASE OF AN INDONESIAN INSURANCE COMPANY
}

\author{
Mahir Pradana ${ }^{1}$, Mahendra Fakhri ${ }^{2}$, Alini Gilang ${ }^{3}$, Puti Khairin ${ }^{4}$ \\ ${ }^{1234}$ Telkom University, Indonesia
}

\begin{abstract}
A company's human resource aspect can gain benefit from extra-role behaviors known as organizational citizenship behavior (OCB). This research discusses about organizational citizenship behavior (OCB) of the employees at an insurance company based in Jakarta, Indonesia. The purpose of this research to analyze the dominant factors that influence OCB in the company. Factors affecting the OCB are altruism, conscientiousness, sportsmanship, courtesy and civic virtue. The type of research used is descriptive with quantitative method. The respondents were 66 employees of Satria Muda Sucore Agency. The sampling technique using probability sampling with simple random sampling type and using factor analysis method. The results of research showed that OCB is in the decent and more to 'high' category. This research formed five factors that are tolerance factor, help behavior factor, compliance factor, participation factor and loyalty factor. Tolerance factor is the most dominant factor of OCB.
\end{abstract}

Keywords: human resource management, organizational citizenship behavior, organizational behavior, personnel management, workplace harmony

\section{FAKTOR-FAKTOR PENENTU ORGANIZATIONAL CITIZENSHIP BEHAVIOR: STUDI KASUS PERUSAHAAN ASURANSI DI INDONESIA}

\begin{abstract}
ABSTRAK
Aspek sumber daya manusia suatu perusahaan dapat memperoleh manfaat dari perilaku tak terikat tugas yang dikenal sebagai perilaku kewargaan karyawan atau organizational citizenship behavior (OCB). Penelitian ini membahas tentang OCB para karyawan di Satria Muda Sucore Agency, sebuah perusahaan asuransi yang berbasis di Jakarta, Indonesia. Tujuan penelitian ini untuk menganalisis faktor-faktor dominan yang mempengaruhi OCB di perusahaan tersebut. Faktor-faktor yang mempengaruhi $O C B$ adalah altruisme, hati nurani, sportivitas, kesopanan dan kebajikan sipil. Jenis penelitian yang digunakan adalah deskriptif dengan metode kuantitatif. Responden adalah 66 karyawan Satria Muda Sucore Agency. Teknik pengambilan sampel menggunakan probability sampling dengan tipe simple random sampling dan menggunakan metode analisis faktor. Hasil penelitian menunjukkan bahwa level OCB termasuk dalam kategori tinggi. Penelitian ini juga menyimpulkan lima faktor yaitu faktor toleransi, faktor tingkah laku, faktor kepatuhan, faktor partisipasi dan faktor loyalitas. Faktor toleransi adalah faktor yang paling dominan dari $O C B$ di perusahaan tersebut..
\end{abstract}

Kata-kata Kunci: perilaku kewargaan karyawan, manajemen sumber daya manusia, manajemen personalia, perilaku organisasi, harmoni tempat kerja

Korespondensi: Mahir Pradana, S.E., M.Sc. Telkom University. Jln. Terusan Buah Batu, Bandung, 40257. Email: mahirpradana@telkomuniversity.ac.id

Submitted: March 2018, Accepted: August 2018, Published: September 2018

ISSN: 1412 - 3681 (printed), ISSN: 2442 - 4617 (online), Website: http://journal.feb.unpad.ac.id/index.php/jbm 
Jurnal Bisnis dan Manajemen, Volume 19, No. 2, September 2018, p. 88-100

\section{INTRODUCTION}

It has been discussed in various organizational literature and experiments that human resource is one of the important factors which determine the success of an organization (Lloyd et al., 2015). Furthermore, human resources management is always regarded as important, because when the sector is not well managed, it will decline other aspects of the organization (Newman et al., 2017).

This is also a reason why experts have developed the field organizational behavior, as a field of science that studies human interaction within the organization including a systematic study of the employee's behavior, as well as the structure and process within the organization (Fakhri et al., 2014). For decades, 'Organizational Behavior' is known as a general term that refers to the attitudes and behaviors of individuals and groups within the organization, relating to the systematic study of attitudes and behaviors, both personal and interpersonal in the organizational context (Pradana \& Wijaksana, 2017).

Each discipline has a purpose, and so is organizational behavior. According to Robbins and Judge (2015), understanding organizational behavior means investigating the roles of individuals, groups and structures within the organization with the aim of applying such knowledge to improve organizational effectiveness. Furthermore, the purpose of understanding organizational behavior is to be able to predict the workers' behavior to gain a significant advantage because by then good communications can be established, which leads to better understanding inside work environment. By being able to predict the behavior of other workers, one can behave and act appropriately in communicating with their workmates (Fakhri et al., 2014).

Organizational behavior is a method that allows us to predict future employee behaviors which might play an important role in an organization or company (Organ \& Paine, 1999). Management will need to explain the various events that occur within the organization (Fakhri et al., 2014). Here, the discipline is required to answer the questions such as why an event occurred, why employees act lazily and other indications. By studying organizational behavior, we try to explain or provide answers to such questions (Lam et al., 2015; DiPaola \& Tschannen-Moran, 2014).

Bolino et al., (2015) believe that the purpose of studying organizational behavior is also to control. The more we can predict and adequately explain individual or group behaviors in the organization, the leaders of the organization will be able to perform better control on their employees so that individual and group behavior will act positively and focus on achieving the goal (Lam et al., 2015). Destructive behavior, moreover, can be also be avoided or prevented (Pradana \& Wijaksana, 2017).

Currently, many companies expect employees or in this case their human resources to be able to do the work in accordance with their responsibilities. The extra-role's behavior concept is also known as organizational citizenship 
Jurnal Bisnis dan Manajemen, Volume 19, No. 2, September 2018, p. 88-100

behavior $(\mathrm{OCB})$. OCB is a form of behavior that begins as a choice and individual initiative, unrelated to the organization's formal reward system but then aggregates and enhances organizational effectiveness (Organ \& Paine, 1999; Borman \& Motowidlo, 2014). According to Robbins \& Judge (2015), organizations whose employees are already familiar with OCB have the advantage to those who are not.

Some experts believe that OCB is the concept of individual behaviors that explicitly or indirectly recognized by the formal system, and in aggregate functions effectively and efficiently in an organization or team (Organ \& Paine, 1999; Boiral et al., 2015). Studying these behaviors is essential in the fields of psychology and human resource management since there has been huge need for the management level of companies to align those behaviors for their future directions or goals (Pangarso et al., 2017).

There have been several research papers that focus on Organizational Citizenship Behavior (OCB) of employees in various fields of work, for example DiPaola \& Tschannen-Moran (2014) who focused on education system, Bolino et al., (2015) on consumer goods companies and Garg (2018) and Fu et al., (2014) on insurance companies.

Recent literature such as Garg (2018) and Fu et al., (2014) explored more on this topic in the insurance business of developing countries, India and China. However, we have not found many of related researches on this topic in Indonesian insurance company. For this reason, we decided to add some insight on this topic with the insurance company as the focus.

In the case of insurance companies, the constructive behaviors are required to be developed and maintained, since the core business of this kind of business is to improve the assurance and quality of human life (Garg, 2018). Based on that short explanation above, we initiated this research. Our primary objective is to find out how OCB plays a role in an Indonesian insurance company. In this case, we chose Satria Muda Sucore Agency as our research object.

Satria Muda Sucore Agency is an insurance company based in Jakarta, Indonesia. We conducted a preliminary survey by distributing questionnaires to 15 employees of Satria Muda Sucore Agency's central office. The results of the survey can be seen in table 1 . 
Table 1 Preliminary Survey Results about Organizational Citizenship Behavior (OCB)

\begin{tabular}{cccccc}
\hline Variable & Altruism & Conscientiousness & Sportsmanship & Courtesy & Civic Virtue \\
\hline Means & 3,867 & 3,467 & 3,3 & 3,6 & 3,4 \\
Integrations & 4 & 4 & 3 & 4 & 3 \\
Category & Good/ Agree & Good/Agree & $\begin{array}{c}\text { Enough Good/ } \\
\text { Can't Agree } \\
\text { Enough }\end{array}$ & $\begin{array}{c}\text { Good/Agree } \\
\text { Enough Good/ } \\
\text { Can't agree } \\
\text { Enough }\end{array}$ & \\
\hline
\end{tabular}

Source: Author's interpretation of preliminary survey

From the preliminary survey results, we see that on most respondents agree, that their workplace has implemented OCB in both categories. Based on information obtained from the company's internal management, the employees have implemented OCB in terms of altruism, conscientiousness, sportsmanship, and civic virtue. Our main source believed that adequate level of OCB at Satria Muda Sucore Agency main office has contributed to their performance level which is reviewed annually. The annual performance level can be seen in the table 2 .

Table 2 Employee Performance Satria Muda Sucore Agency 2016

\begin{tabular}{cccc}
\hline Level & $\begin{array}{c}\text { Valida } \\
\text { tion }\end{array}$ & $\begin{array}{c}\text { Number } \\
\text { of } \\
\text { employee } \\
\text { validation }\end{array}$ & $\begin{array}{c}\text { Number of } \\
\text { employee } \\
\text { terminated }\end{array}$ \\
\hline Agency & 1 & 3 & - \\
Director & $\begin{array}{c}\text { billion } \\
\text { rupiahs }\end{array}$ & & \\
Area Sales & $\begin{array}{c}550 \\
\text { million } \\
\text { Manager }\end{array}$ & 2 & - \\
rupiahs & & \\
District & $\begin{array}{c}300 \\
\text { million } \\
\text { Manager }\end{array}$ & 6 & - \\
Unit & $\begin{array}{c}100 \\
\text { rupiahs }\end{array}$ & 21 & - \\
Manager & $\begin{array}{c}\text { million } \\
\text { rupiahs } \\
\text { Executive }\end{array}$ & & \\
Financial & million & 259 & \\
Consultant/ & rupiahs & & - \\
Agent & & & \\
\hline
\end{tabular}

Source: internal data of Satria Muda Sucore Agency

From the data in table 2, it can be seen that the employee performance is in the decent category. Based on the information obtained from their Area Sales Manager, Satria Muda Sucore Agency employees performances are in right category, where all employees have reached the target or validation set by the company. Employees who have reached the target or validation indicate that the employee has performed well. In this case, if the employee does not reach the target or validation, then the employee will terminate automatically.

Based on what has been described previously, the evidence shows that OCB has been implemented by the employees Satria Muda Sucore Agency. Since there has been an initial indication that OCB is well implemented, as researchers we would like to know deeper about the aspects of OCB that employees have appropriately applied.

Therefore, the purpose of this research is to analyze the level of employee's organizational citizenship behavior as well as what dominant factors influence organizational citizenship 
Jurnal Bisnis dan Manajemen, Volume 19, No. 2, September 2018, p. 88-100

behavior at Satria Muda Sucore Agency financial company.

\section{LITERATURE REVIEW}

According to Sedarmayanti (2017), the principles of human resource management are utilizing human resources effectively and efficiently through the activities of planning, moving, and controlling all values that become a human strength to achieve the goal. Furthermore, according to Robbins \& Judge (2015), organizational behavior is a field of study that invests the influence of individuals, groups, and structures on behavior within the organization, to apply knowledge for the improvement of organizational effectiveness (Newman et al., 2015).

As explained before, organizational citizenship behavior (OCB) is a form of behavior that is an individual's choice and initiative, unrelated to the organization's formal reward system but aggregated enhancing organizational effectiveness (DiPaola \& Tschannen-Moran, 2014; Lam et al., 2015). Earlier research suggested that the first factor affecting OCB is altruism, which is the behavior of employees in helping his colleagues who have difficulty in the situation that is facing both the task in the organization and personal problems of others $(\mathrm{Ng}$ \& Feldman, 2016). The next one is conscientiousness, which is the behavior exhibited by trying to exceed the organizational's expectations (Fakhri et al., 2014) which leads to voluntary behavior that is not an employee's basic duties (Koning \& Van Kleef, 2014). Afterwards, there is a factor of sportsmanship, which is the behavior that tolerates less ideal circumstances within the organization without raising objections (Lam et al., 2015). A person who has a high level in sportsmanship will improve a positive climate among employees, in which they tend to be more polite and cooperate with others so that will create a more enjoyable work environment (Shin et al., 2017).

OCB also relies on courtesy, which is maintaining good relations with colleagues to avoid interpersonal problems and civic virtue, behavior that indicates responsibility for organizational life (following changes in the organization, taking initiatives to recommend how operations or organizational procedure can be improved, and protecting resources owned by the organization) (DiPaola \& Tschannen-Moran, 2014). Good employee performance requires the appropriate behavior of teachers expected by the organization. The behavior that the organization demands today is not only in-role behavior but also extra-role behavior (Lam., 2015).

As a social being, man can have empathy for others and his environment and harmonize his values (Pradana \& Wijaksana, 2017). With the values that are uphold, a man in a workplace will promote better social interaction (Van den Heuvel et al., 2015). Moreover, man is not always driven by things that benefit him, for example, someone willing to help others if there are certain rewards. If most employees behave like this, then the 
Jurnal Bisnis dan Manajemen, Volume 19, No. 2, September 2018, p. 88-100

organization can be said to already possess OCB culture (Dixon et al., 2015).

To choose the best behavior for the benefit of his organization, Van den Heuvel et al., (2015) stated that OCB can improve organizational performance because this behavior is the "lubricant" of the social machine in the organization. in other words, with this behavior, the social interaction on the members of the organization becomes smooth, disputes, and increased efficiency. This behavior arises because of feelings as members of the organization and feel satisfied if it can do something more to the organization, does not pay attention to self-interest (Sloat, 1999), does not require job description and formal reward system (Lam et al., 2015), and voluntary in cooperation with co-workers and receives special orders without complaint (DiPaola \& Tschannen-Moran, 2014).

OCB also contributes to the well-being of its community, resource transformation, innovation and adaptation (DiPaola \& TschannenMoran, 2014), including improving the effectiveness and efficiency of deployment of scarce resources, work units in a collective and interdependent way. It will also influence compensation, promotion and training decisions and have important effects on financial performance (Organ \& Paine, 1999; Boiral et al, 2015). In addition, OCB is often seen as a determinant for human resource management program in supervising, maintaining and improving work attitude (Pradana \& Wijaksana, 2017). This concept leads organizations to be more innovative, flexible, productive, and responsive (Titisari, 2014).

OCB includes some positive behaviors including the behavior of helping others, volunteering for extra tasks, obeying the rules and procedures of the workplace (Dixon et al., 2015). These behaviors indicate the added value of employees which is one form of pro-social behavior (Fakhri et al., 2014)

Understanding OCB as a free individual behavior, not directly or explicitly related to the reward system and can improve the effective functioning of the organization. Furthermore, DiPaola \& Tschannen-Moran (2014), argues that what is meant to function in aggregate is to refer to people in a group, department, or organization. If only one person, OCB has no significant impact on an organization, however, if within an organization, its members have good level of $\mathrm{OCB}$, the impact on the organization will spread significantly (Fakhri et al., 2014).

Pesta et al., (2015) provided an example by comparing two employees who have the same qualities in a job. One of them is not willing to work until late and only wants to work according to his working hours, while one of the others is willing to work late even though it is outside his working hours, he is also willing to help his boss whenever needed. According to them, the second type of individual has a better OCB. In this case, the free and spontaneous behavior of individuals resulting from one's character which forms the character of the organization, also derives from the relationship with the superior. This behavior is 
Jurnal Bisnis dan Manajemen, Volume 19, No. 2, September 2018, p. 88-100

done to the organization or co-worker, resulting in increased organizational effectiveness through the direct influence of the work or indirect social influences based on interpersonal relationship enhancement (Koning \& Van Kleef, 2014).

The will or desire to tolerate the inconvenience that arises, the employee's commitment to the company thoroughly, helping behavior, organizational loyalty, organizational compliance, individual initiative, and selfdevelopment are the voluntary behavior of individuals seen as basic principles of OCB (DiPaola \& Tschannen-Moran, 2014). These points can be improved by enhancing their knowledge, skills and abilities such as attending courses, training, seminars or keeping up with the latest developments of the dominated field (Pesta et al., 2015).

DiPaola \& Tschannen-Moran (2014) also argued that there are three motives of OCB, including achievement motives, affiliation motives and power motives. Achievement motives are the ones that support people to describe a special excellence standard, seeking achievement from a task, opportunity or competition. Behaviors such as helping others, talking about change can affect others, strive not to complain and participate in unit meetings and the things that make up the OCB count as the key to success.

Affiliate motives support people to realize, maintain and improve relationships with others. Affiliation is an extra-role behavior involving OCB and pro-social behavior to establish and maintain relationships with other people or organizations because they place the value of others and cooperative relationships, while power motive supports people to search for the status and circumstances in which they can control the work or behavior of others (Pesta et al., 2015; Koning \& Van Kleef, 2014). Individuals whose orientation to power assume $\mathrm{OCB}$ is a tool that acquires power and status with authority figures within the organization (DiPaola \& Tschannen-Moran, 2014).

Last but not least, of course, there are benefits to OCB. Dixon et al., (2015) and Boiral et al., (2015), believe that the benefits are to increase the productivity of managers and co-workers, maximize the use of resources, effective teamwork and improve the organization's ability to recruit and retain employees with good quality performance. One can also see that maintaining organizational performance stability helps the organization's ability to maintain and adapt to environmental change, as well as to create enhanced capabilities and social capital are also among the benefits (Lam et al., 2015).

\section{METHODS}

The type of research used is descriptive research with a quantitative method. The population in this research is Satria Muda Sucore Agency employee with 187 employees. To determine the number of research samples, the researchers used Slovin formula with error level $10 \%$ so that the number of samples in this study was as many as 66 respondents. Data analysis technique used is descriptive analysis and factor analysis. 
Jurnal Bisnis dan Manajemen, Volume 19, No. 2, September 2018, p. 88-100

Factor analysis is one multivariate analysis family that aims to summarize or reduce the variable of observation as a whole into several new variables or dimensions, but the new variables or dimensions are still able to represent the main variables (Wardhana \& Pradana, 2016). In the factor analysis, two main approaches are known, namely exploratory factor analysis and confirmatory factor analysis. We use exploratory factor analysis if the number of factors formed is not determined first. Confirmatory factor analysis is used when the established factor has been established first (Kline, 2014).

The underlying assumption that should be underlined in factor analysis is that the variables analyzed are related or interrelated because the factor analysis seeks to look for the universal dimension underlying those variables (Kline, 2014). The main purpose of factor analysis is to explain the relationship structure among many variables in the form of a factor or latent variant or formed variable. Factors formed are random quantities that previously could not be observed or measured or determined directly.

In addition to the main purpose of factor analysis, there are other objectives, which are to reduce the number of many of the original variables into some new variables that are fewer than the original variables, and the new variable is called the latent factor or variable or construct or form variable. Second, to identify the relationship between the variables of the factors or dimensions with the factors formed, by testing the correlation coefficient between factors with its constituent components (Kline, 2014).

Beforehand, we also have to test the validity and reliability of the instrument with confirmatory factor analysis. Validation of data to determine whether the results of factor analysis can be generalized into the population, so after the formed factor, a new hypothesis based on the results of factor analysis can be presented (Wardhana \& Pradana, 2016). In principle, factor analysis can then be interpreted according to the factors or components or constructs that are formed. In an exploratory factor analysis where the researcher does not or does not yet have knowledge or theory or a hypothesis that constructs the structure of the factors to be formed or formed, so that in exploratory factor analysis is a technique to help construct a new theory (Kline, 2014).

The purpose of confirmatory factor analysis is first to identify the relationship between variables by conducting a correlation test. The second objective is to test the validity and reliability of the instrument. In testing of the validity and reliability of the instrument or questionnaire to obtain valid and reliable research data (Wardhana \& Pradana, 2016).

From the descriptive analysis, the overall organizational citizenship behavior (OCB) of Satria Muda Sucore Agency employees is in the high category with a percentage value of $73 \%$. This indicates that employees of Satria Muda Sucore Agency have implemented OCB well. 
Jurnal Bisnis dan Manajemen, Volume 19, No. 2, September 2018, p. 88-100

The total factor variables used in this study are five variables, namely altruism, conscientiousness, sportsmanship, courtesy, civic virtue (DiPaola \& Tschannen-Moran, 2014; Boiral et al., 2015; Takeuchi et al., 2015), which is described in 24 statements on the questionnaire. The result of factor analysis can seen in table 3 .

Table 3 KMO and Bartlett's Test

\begin{tabular}{|c|c|c|}
\hline \multicolumn{2}{|c|}{ KMO and Bartlett's Test } & Score \\
\hline \multicolumn{2}{|c|}{$\begin{array}{l}\text { Kaiser-Meyer-Olkin Measure } \\
\text { of Sampling Adequacy. }\end{array}$} & .837 \\
\hline $\begin{array}{l}\text { Bartlett's Test of } \\
\text { Sphericity }\end{array}$ & $\begin{array}{l}\text { Approx. } \\
\text { Chi- } \\
\text { Square } \\
\text { df }\end{array}$ & $\begin{array}{r}1139.35 \\
8\end{array}$ \\
\hline & Sig. & .000 \\
\hline
\end{tabular}

In table 3, the KMO Measure of Sampling Adequacy is 0.837 . The MSA KMO score greater than 0.5 indicates that a set of variable factors can further be processed using factor analysis. This assumption is strengthened by Kline (2014) and Wardhana \& Pradana (2016) about the experience of further steps in factor analysis. It can also be seen the Barlett's Test of Sphericity (shown with the Chi-Square number) of 1139,358 with a significance of 0,000 which means $100 \%$ reliable and the variables were correlated.

\section{RESULTS AND DISCUSSION}

Previous research (Bolino et al., 2015 \& Carter et al., 2014) have shown that supervisors and subordinated differ in their perceptions. Based on these findings, we expect that the respondent is likely to influence different types of OCB.
Table 4 Anti-Image Matrices

\begin{tabular}{lll}
\hline No. & Variables & MSA \\
\hline 1. & X1 & 0.927 \\
2. & X2 & 0.858 \\
3. & X3 & 0.890 \\
4. & X4 & 0.810 \\
5. & X5 & 0.844 \\
6. & X6 & 0.647 \\
7. & X7 & 0.854 \\
8. & X8 & 0.900 \\
9. & X9 & 0.855 \\
10. & X10 & 0.902 \\
11. & X11 & 0.769 \\
12. & X12 & 0.821 \\
13. & X13 & 0.843 \\
14. & X14 & 0.819 \\
15 & X15 & 0.878 \\
16. & X16 & 0.867 \\
17. & X17 & 0.625 \\
18. & X18 & 0.806 \\
19. & X19 & 0.786 \\
20. & X20 & 0.850 \\
21. & X21 & 0.847 \\
22. & X22 & 0.866 \\
23. & X23 & 0.885 \\
24. & X24 & 0.899 \\
\hline & &
\end{tabular}

In table 4 it can be seen that the value of MSA in each factor is at $>0.5$, which means that any existing factors can be predicted and analyzed further. The next step is to see the communalities table. According to Kline (2014), it is the table which shows the degree of the factors which are formed can explain the variables: 
Jurnal Bisnis dan Manajemen, Volume 19, No. 2, September 2018, p. 88-100

Table 5 Communalities

\begin{tabular}{lcc}
\hline \multicolumn{3}{c}{ Communalities } \\
\hline & Initial & Extraction \\
\hline X1 & 1.000 & .764 \\
X2 & 1.000 & .782 \\
X3 & 1.000 & .650 \\
X4 & 1.000 & .794 \\
X5 & 1.000 & .695 \\
X6 & 1.000 & .811 \\
X7 & 1.000 & .609 \\
X8 & 1.000 & .701 \\
X9 & 1.000 & .642 \\
X10 & 1.000 & .743 \\
X11 & 1.000 & .749 \\
X12 & 1.000 & .820 \\
X13 & 1.000 & .670 \\
X14 & 1.000 & .725 \\
X15 & 1.000 & .704 \\
X16 & 1.000 & .630 \\
X17 & 1.000 & .597 \\
X18 & 1.000 & .692 \\
X19 & 1.000 & .668 \\
X20 & 1.000 & .716 \\
X21 & 1.000 & .807 \\
X22 & 1.000 & .668 \\
X23 & 1.000 & .705 \\
X24 & 1.000 & .619 \\
\hline
\end{tabular}

Extraction Method: Principal

Component Analysis.

Table 5 shows that the variable $\mathrm{X} 12$ has the highest value of 0.820 which means $82 \%$ variant X12 variables can be explained by the new components that were formed. So forth for other variables, provided that the greater the communalities of a variable, the more closely related to the new components were formed.

Table 6 Rotated Component Matrix

\begin{tabular}{lccccc}
\hline \multicolumn{5}{c}{ Component } \\
& $\mathbf{1}$ & $\mathbf{2}$ & $\mathbf{3}$ & $\mathbf{4}$ & $\mathbf{5}$ \\
\hline $\mathrm{X} 1$ & .197 & .726 & .402 & .143 & .123 \\
$\mathrm{X} 2$ & .112 & .712 & .444 & .168 & .194 \\
$\mathrm{X} 3$ & .479 & .518 & .053 & .352 & .159 \\
$\mathrm{X} 4$ & .512 & .612 & -.032 & .236 & .317 \\
$\mathrm{X} 5$ & .386 & .604 & .304 & .298 & .015 \\
$\mathrm{X} 6$ & .053 & .860 & .117 & -.024 & .232 \\
$\mathrm{X} 7$ & .048 & .208 & .214 & .700 & .167 \\
$\mathrm{X} 8$ & .215 & .439 & .407 & .427 & .337 \\
$\mathrm{X} 9$ & .398 & .046 & -.066 & .657 & .213 \\
$\mathrm{X} 10$ & .197 & .020 & .268 & .666 & .434 \\
$\mathrm{X} 11$ & .325 & .286 & .301 & .551 & -.410
\end{tabular}

\begin{tabular}{lrrrrr}
$\mathrm{X} 12$ & .850 & .248 & .123 & -.050 & .140 \\
$\mathrm{X} 13$ & .712 & .168 & .299 & .209 & .036 \\
$\mathrm{X} 14$ & .119 & .341 & .148 & .397 & .644 \\
$\mathrm{X} 15$ & .226 & .235 & .191 & .101 & .743 \\
$\mathrm{X} 16$ & .606 & .179 & .362 & .315 & -.023 \\
$\mathrm{X} 17$ & .674 & .019 & -.004 & .163 & .341 \\
$\mathrm{X} 18$ & .665 & .120 & .268 & .378 & .145 \\
$\mathrm{X} 19$ & .157 & .476 & .552 & .174 & .286 \\
$\mathrm{X} 20$ & .290 & .198 & .697 & .202 & .255 \\
$\mathrm{X} 21$ & .085 & .212 & .840 & .178 & .130 \\
$\mathrm{X} 22$ & .156 & .219 & .315 & .183 & .680 \\
$\mathrm{X} 23$ & .313 & .253 & .339 & .433 & .491 \\
$\mathrm{X} 24$ & .402 & .278 & .541 & -.005 & .295 \\
\hline $\mathrm{Ex}$ & & &
\end{tabular}

Extraction Method: Principal Component Analysis.

Rotation Method: Varimax with Kaiser Normalization.

a. Rotation converged in 9 iterations.

Table 6 above shows the rotation of the component matrix. The rotated component matrix table can show the right variables to enter into factors $1,2,3,4$, or 5 , so this makes it easy to group factors.

Table 7 Labelling

\begin{tabular}{ccc}
\hline Factor & Variables & $\begin{array}{c}\text { Factor } \\
\text { Loading }\end{array}$ \\
\hline Tolerance & X12 & 0.850 \\
& X13 & 0.712 \\
& X17 & 0.674 \\
& X18 & 0.665 \\
Helping & X16 & 0.606 \\
Behavior & X6 & 0.860 \\
& X1 & 0.726 \\
& X2 & 0.712 \\
& X4 & 0.612 \\
& X5 & 0.604 \\
Compliance & X3 & 0.518 \\
& X8 & 0.439 \\
& X7 & 0.700 \\
& X10 & 0.666 \\
Participation & X9 & 0.657 \\
& X11 & 0.551 \\
& X21 & 0.840 \\
& X20 & 0.697 \\
& X19 & 0.552 \\
& X24 & 0.541 \\
& X15 & 0.743 \\
& X22 & 0.680 \\
& X14 & 0.644 \\
& X23 & 0.491 \\
\hline
\end{tabular}


Jurnal Bisnis dan Manajemen, Volume 19, No. 2, September 2018, p. 88-100

In this research, the method of labelling factors based on eigenvalue is a factor with an eigenvalue greater than one maintained, if less than one factor is not included in the model. Based on the factor analysis process, in the end, formed five factors that we found in this research are tolerance factor, help behavior factor, compliance factor, participation factor and loyalty factor. These results, more or less, confirm the existing research conclusions by Boiral et al. (2015), which focuses on the impact of environment and internal management role on employee's behavior, and Takeuchi et al., (2015), which focused more on the interpersonal relationship.

\section{CONCLUSION}

Based on the results of the research of Organizational Citizenship Behavior (OCB) Factors on Satria Muda Sucore Agency employees, we found the conclusion that the percentage of OCB of Satria Muda Sucore Agency employee is $73 \%$, which is included in 'high' category. This indicates that the OCB of employees has been well implemented.

There are five factors formed from OCB; the five factors were named as tolerance factor, help behavior factor, compliance factor, participation factor and loyalty factor. Tolerance factor is the most dominant factor influencing OCB. If we confirm this result with our pre-research interview, we found on Table 1 that altruism is the most obvious factor at Satria Muda Sucore Company. Several previous types of research such as Takeuchi et al., (2015) and DiPaola \&
Tschannen-Moran (2014) have agreed that 'altruism' and 'tolerance' more or less have similarity. Thus we agreed to synchronize those two factors.

In general, the OCB is proven as the behavior that is not in the job description, and there is no reward for the related actions. The workers behave at their own will, such as helping other colleagues (factor number 2). This behavior was also reflected in our preliminary survey (conscientiousness), which defines the behavior of assisting teammates in completing certain tasks. This behavior, in the end, can improve organizational effectiveness.

Based on the theories and synthesis already discussed OCB beforehand, the rest of the indicators that can be drawn up are already explained above. The indicators are organized based on the existing dimensions and more or less similar to what has been proven through researches in the same topic, in the end, these five factors can be taken as dimensions for further research on the level of OCB in an organization.

\section{REFERENCES}

Boiral, O., Talbot, D., \& Paillé, P. (2015). Leading by example: A model of organizational citizenship behavior for the environment. Business Strategy and the Environment, 24(6), 532-550.

Bolino, M. C., \& Klotz, A. C. (2015). The paradox of the unethical organizational citizen: The link between organizational citizenship behavior and unethical behavior at work. Current Opinion in Psychology, 6, 45-49.

Borman, W. C., \& Motowidlo, S. J. (Eds.). (2014). Organizational citizenship behavior and contextual performance: A special issue of human performance. Psychology Press. 
Jurnal Bisnis dan Manajemen, Volume 19, No. 2, September 2018, p. 88-100

Carter, M. Z., Mossholder, K. W., Feild, H. S., \& Armenakis, A. A. (2014). Transformational leadership, interactional justice, and organizational citizenship behavior: The effects of racial and gender dissimilarity between supervisors and subordinates. Group \& Organization Management, 39(6), 691-719.

DiPaola, M., \& Tschannen-Moran, M. (2014). Organizational citizenship behavior in schools and its relationship to school climate. Journal of School Leadership, 11(5), 424-447.

Dixon, G. N., Deline, M. B., McComas, K., Chambliss, L., \& Hoffmann, M. (2015). Using comparative feedback to influence workplace energy conservation: A case study of a university campaign. Environment and Behavior, 47(6), 667-693.

Fakhri, M., Aditya, M., \& Pradana, M. (2014). Factor analysis of work motivation using Maslow's hierarchy of needs: Case study on civil servants at Banten Province's Office of Agriculture and Livestock. In International Conference on Emerging Trends in Academic Research (pp. 258274).

Fu, W., \& Deshpande, S. P. (2014). The impact of caring climate, job satisfaction, and organizational commitment on job performance of employees in a China's insurance company. Journal of Business Ethics, 124(2), 339-349.

Garg, N. (2018). Promoting Organizational Performance in Indian Insurance Industry: The Roles of Workplace Spirituality and Organizational Citizenship Behavior. Global Business Review, 0972150918778983.

Kline, P. (2014). An easy guide to factor analysis. Routledge.

Koning, L. F., \& Van Kleef, G. A. (2015). How leaders' emotional displays shape followers' organizational citizenship behavior. The Leadership Quarterly, 26(4), 489-501.

Lam, C. F., Liang, J., Ashford, S. J., \& Lee, C. (2015). $\mathrm{Job}$ insecurity and organizational citizenship behavior: Exploring curvilinear and moderated relationships. Journal of Applied Psychology, 100(2), 499.

Lloyd, K. J., Boer, D., Keller, J. W., \& Voelpel, S. (2015). Is my boss really listening to me? The impact of perceived supervisor listening on emotional exhaustion, turnover intention, and organizational citizenship behavior. Journal of Business Ethics, 130(3), 509-524.

Newman, A., Schwarz, G., Cooper, B., \& Sendjaya, S. (2017). How servant leadership influences organizational citizenship behavior: The roles of
LMX, empowerment, and proactive personality. Journal of Business Ethics, 145(1), 49-62.

Ng, T. W., Lam, S. S., \& Feldman, D. C. (2016). Organizational citizenship behavior and counterproductive work behavior: Do males and females differ?. Journal of Vocational Behavior, 93, 11-32.

Organ, D. W., \& Paine, J. B. (1999). A new kind of performance for industrial and organizational psychology: Recent contributions to the study of organizational citizenship behavior. Human resource management review, Elsevier

Pangarso, A., Syarifuddin, M. P., Moeliono, N., \& Fazrido, B. M. (2017). The Influence of Transformational Leadership Style on Employee's Performance PT PLN Cabang Pekanbaru Rayon Panam.

Pesta, B. J., McDaniel, M. A., Poznanski, P. J., \& DeGroot, T. (2015). Discounting IQ's Relevance to Organizational Behavior: The "Somebody Else's Problem" in Management Education. Open Differential Psychology, 1.

Pradana, M., \& Wijaksana, T. I. (2017). Managing Work Productivity Through Management of Information System (Study on Telkom Indonesia Online Portal). Advanced Science Letters, 23(1), 64-66.

Robbins, Stephen P. \& Judge Timothy A. (2015). Perilaku Organisasi (Organizational Behavior). Jakarta: Salemba Empat.

Sedarmayanti. (2017). Perencanaan dan Pengembangan SDM untuk Meningkatkan Kompetensi, Kinerja, dan Produktivitas Kerja (Planning and HR Development to improve Competence, Performance, and Work Productivity). Bandung: PT. Refika Aditama.

Shin, Y., Kim, M. S., Choi, J. N., Kim, M., \& Oh, W. K. (2017). Does leader-follower regulatory fit matter? The role of regulatory fit in followers' organizational citizenship behavior. Journal of Management, 43(4), 1211-1233.

Sloat, KC (1999). Organizational Citizenship: Does Your Firm Inspire to be "Good Citizenship?". Professional Safety. Vol.44:20-23

Takeuchi, R., Bolino, M. C., \& Lin, C. C. (2015). Too many motives? The interactive effects of multiple motives on organizational citizenship behavior. Journal of Applied Psychology, 100(4), 1239.

Titisari, Purnamie. (2014). Peranan Organizational Citizenship Behavior (OCB) dalam Meningkatkan Kinerja Karyawan (The role of Organizational Citizenship Behavior (OCB) in Improving Employee Performance). Jakarta: Mitra Wacana Media. 
Jurnal Bisnis dan Manajemen, Volume 19, No. 2, September 2018, p. 88-100

Van den Heuvel, S., Schalk, R., \& van Assen, M. A. (2015). Does a well-informed employee have a more positive attitude toward change? The mediating role of psychological contract fulfillment, trust, and perceived need for change. The Journal of Applied Behavioral Science, 51(3), 401-422.

Wardhana, A., \& Pradana, M. (2016). Viral Marketing Determinants of Top Online Shop Brands in Indonesia. Mimbar: Jurnal Sosial dan Pembangunan, 32(1), 25-30. 